\title{
Transport Modeling Analysis to Test the Efficiency of Fish Markets in Oman
}

\section{Khamis S. Al-Abri, Hemesiri Kotagama*, Andrew Palfreman and Houcine Boughanmi}

\author{
Department of Natural Resource Economics \\ College of Agricultural and Marine Sciences, Sultan Qaboos University \\ P.O. Box 34, Al Khod 123, Sultanate of Oman \\ تحليل نماذج النقل لإختبـار كفاءة أسواق الأسماك العمانية \\ خميس العبري وهمسيري كوتقاما" وأندرو بالفيرمان وحسين البوغانمي
}

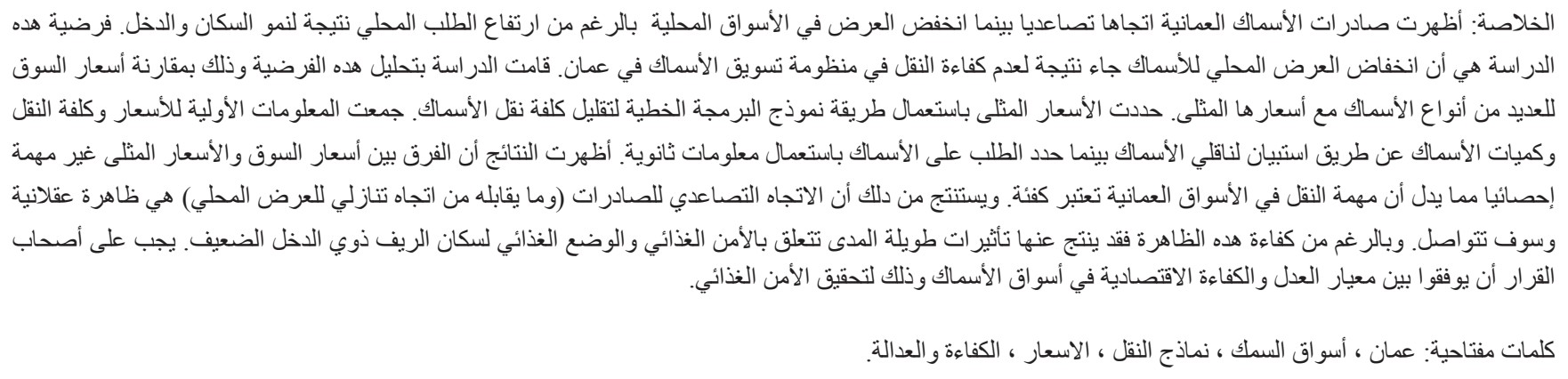

ABSTRACT: Oman's fish exports have shown an increasing trend while supplies to the domestic market have declined, despite increased domestic demand caused by population growth and income. This study hypothesized that declining fish supplies to domestic markets were due to inefficiency of the transport function of the fish marketing system in Oman. The hypothesis was tested by comparing the observed prices of several fish species at several markets with optimal prices. The optimal prices were estimated by the dual of a fish transport costminimizing linear programming model. Primary data on market prices and transportation costs and quantities transported were gathered through a survey of a sample of fish transporters. The quantity demanded at market sites was estimated using secondary data. The analysis indicated that the differences between the observed prices and the estimated optimal prices were not significantly different showing that the transport function of fish markets in Oman is efficient. This implies that the increasing trend of fish exports vis-à-vis the decreasing trend of supplies to domestic markets is rational and will continue. This may not be considered to be equitable but it is efficient and may have long-term implications for national food security and have an adverse impact on the nutritional and health status of the rural poor population. Policy makers may have to recognize the trade off between the efficiency and equity implications of the fish markets in Oman and make policy decisions accordingly in order to ensure national food security.

Keywords: Oman, fish markets, transport model, prices, efficiency and equity.

\section{Introduction}

The marketing component of the fisheries sector in Oman is changing rapidly from a traditional system restricted to meeting domestic market requirements to a more modern pattern supplying regional and global export markets. Such changes, as evident in other countries, have had beneficial as well as adverse socio-economic effects (Bush, 2004). In Oman, along with the growth of exports of fishery products, the availability of fish in the domestic market has declined despite the increase in population and per capita income. Bush (2004), quoting International Center for Living Aquatic Resource Management (1999), suggests that the interplay of domestic needs and international trade will increasingly make fish a politically sensitive commodity.

Given the bulkiness and perishability of fish, and particularly in Oman because the fish landing sites and domestic markets are geographically widely distributed, the efficiency of fish transportation is an important factor affecting the share of fish available for domestic consumption. This paper presents a quantitative assessment of the efficiency of fish transport in Oman to test if the distribution of fish between domestic and export markets is efficient. The study hypothesized that the domestic demand 


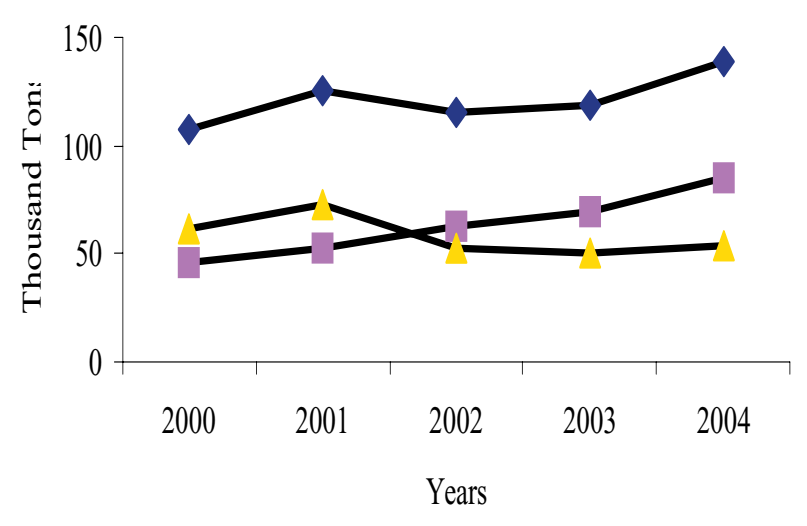

$\rightarrow$-Landed - -Exported - - Domesticaly marketed

Figure1. Fish landed, exported and domestically marketed. Source: MAF (2005).

for fish in Oman is under-supplied vis-à-vis over-supplied to export markets due to inefficiency of the transportation function of Oman's fish market, and concludes by rejecting the hypothesis.

The paper is in four sections. The first section presents a brief summary of the fisheries sector and fish markets in Oman. The second section notes research literature and the third outlines the analytical method. The fourth section presents and interprets the results of the analysis.

\section{Fisheries Sector and Markets in Oman}

The fisheries sector has contributed to about $0.6 \%$ of the Gross Domestic Product and comprised about $1.2 \%$ of the non-oil sector of Oman in 2005 (Ministry of National Economy, 2006). In spite of the small proportionate contribution of the sector to the national economy, fisheries activities have the potential to be a sustainable source of income compared with other nonrenewable natural resources, such as oil and natural gas. Furthermore, fisheries activities provide full time or part time jobs for 20,870 fishermen and 3,250 persons working in fish transportation activities in Oman. Many of these live in rural areas and are relatively poor. Moreover, fisheries activities have been intimately associated with the traditional indigenous heritage and culture of Oman.

Over the years (1996 to 2004), fish exports from Oman have greatly increased. This is despite the increase in domestic demand for fish, resulting from population growth and rising per capita income in the Sultanate (Omezzine et al., 2003). As is evident in Figure 1, during the period 2000 to 2004, the total fish landed in Oman has increased by $29 \%$ and exports have increased by $83 \%$. However, during the same period fish available to the domestic market has decreased by $12 \%$. The trend of decreasing availability of fresh fish in the domestic market may cause concerns among the domestic consumers and in the long run may have adverse implications for the nutritional status and health of the rural poor. This study investigated if the above trend is due to inefficiency of the transport function of the fish market.

\section{Theory and Literature}

Spatial market efficiency can be assessed by examining trade volumes, prices or both. Each measurement has important shortcomings in isolation from the other. Assessment based on trade volume measurement cannot establish whether spatial equilibrium conditions are reached. Assessment based on price data alone does not reveal information about the optimal trading volumes. Al Abri (2008) analyzed the efficiency of fish transport in Oman using both measurements of prices and trade volumes. This paper restricts its analysis of fish market efficiency to price data, for sake of brevity.

Transportation theory and modeling examines the optimal transportation of commodities in markets. The transportation problem can be identified as a network flow problem. It is generalized as a network of a set of $\mathrm{M}$ supply nodes, a set of $\mathrm{N}$ demand nodes, and a set of arcs connecting them. Each supply node $\mathrm{S}_{\mathrm{i}}$ has a fixed amount $\mathrm{s}_{\mathrm{i}}$ of a commodity, which it can supply. Each demand node $D_{j}$ has a fixed demand $d_{j}$ for that commodity, and for each arc $(i, j)$ connecting supply node $S_{i}$ to demand node $D_{j}$ there is an associated cost per unit flow $\mathrm{C}_{\mathrm{ij} j}$. The model is solved by minimizing $\mathrm{C}_{\mathrm{ij}}$ in order to determine the optimal allocation of product from supply nodes to demand nodes. Although often referred to as the transportation model, it can be adapted to simulate the operation of a competitive market. The dual of a transport cost minimization model enables the estimation of competitive equilibrium market prices, given the cost of transportation, and supply and demand constraints (Dorfman, et. al., 1958). Thie (1988) provides comprehensive guidance on the application of linear programming in modeling transportations problems. Transport modeling using linear programming has been extensively used in both, empirical academic research and in practical business management as exemplified by Smith et al. (2007). However empirical application of transport modeling for the fisheries markets is scanty. An example is a study by Borisova et al. (2003). The study examined the potential to increase aquaculture producer and processor profits through improvements in transport management. The study determined the optimal markets and shipment patterns using an integer linear programming model.

Few studies investigating the structure and performance of fish markets in Oman have been done in recent years. Omezzine (1996) reported that fish transporters preferred selling in export markets despite lower prices than those received in domestic markets. Among many factors that explain such behavior is the ability to sell large amounts of fish particularly in Dubai. Al Jabri (1999) analyzed the degree of market integration within Omani fish markets. The study concluded that the Omani fish market was not a perfectly competitive market. A similar study (MAF, 2002), using the same methodology, has confirmed Al Jabri's (1999) conclusion. Omezzine et al. (2003) highlighted the 


\section{Landing sites}

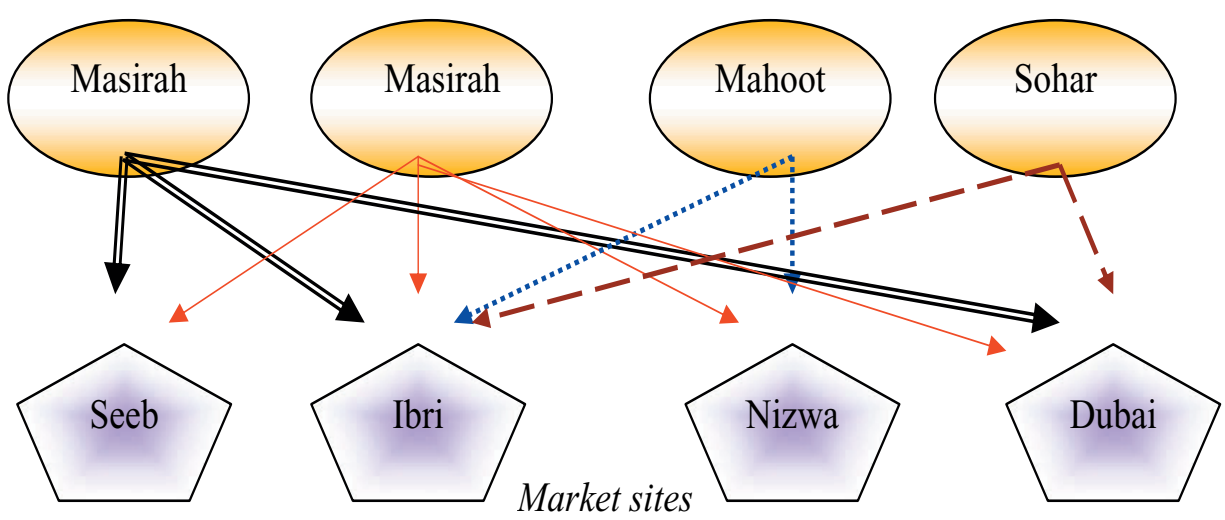

Figure 2. Fish transport routes.

importance of providing market information of potential demand and prices etc, to improve the transportation function of fish markets in Oman.

\section{Methodology}

In order to test the hypothesis that the transport function of the fisheries market in Oman is inefficient, the study compared the observed prices of several fish species at different markets with optimal prices. The optimal market prices were estimated from the dual of fish transport costminimizing linear programming model.

This study was based on the transporting of fresh fish between the landing sites and domestic and export markets by truckers. A purposive sample to best represent fish landing sites and markets in Oman was obtained, in consultation with researchers and experts on fisheries sector. The selected fish landing sites were; Masirah, Mahoot, Jalan and Sohar and the fish market sites were the domestic markets of Nizwa, Ibri, and Seeb. The export market was Dubai. Figure 2 shows the transport routes followed by truckers from landing sites to markets.

The four fish landing sites of the sample represented $21 \%$ of total fish landed by traditional fishermen, $35 \%$ of fish exports and $54 \%$ of fish available for the local market (MAF, 2003 and authors' estimates). The three domestic markets of the sample represented $17 \%$ of Oman's population and $9.5 \%$ of fish consumption in Oman (MNE, 2003). A sample consisting of 60 truckers was interviewed using a structured questionnaire. This sample represented about $2 \%$ of the trucker population (3250 truckers) in Oman. The fish transported by the sample of truckers during the study period was 7255 tons, consisting of kingfish, 29\% (Scomberomorur commerson), sardine, 55\% (Sardinella longiceps), long tail tuna, 9\% (Thunnus tonggol) and scavenger, 7\% (Lethrinus Nebulosus). The analysis explained in detail in this paper is for kingfish. The results of a similar analysis for sardines and a composite of fish are presented.

\section{The Transportation Model}

The primal of the transport cost-minimizing model that was used in the study is given below.

$$
\begin{array}{ll}
\text { Minimize: } & \mathrm{TC}=\Sigma_{\mathrm{i}} \Sigma_{\mathrm{j}} \mathrm{C}_{\mathrm{ij}} * \mathrm{X}_{\mathrm{ij}} \\
\text { Constrained to: } & \Sigma_{\mathrm{j}} \mathrm{X}_{\mathrm{ij}} \leq \mathrm{S}_{\mathrm{i}} \\
& \Sigma_{\mathrm{i}} \mathrm{X}_{\mathrm{ij}} \geq \mathrm{D}_{\mathrm{j}} \\
& \mathrm{X}_{\mathrm{ij}} \geq 0
\end{array}
$$

where:

$\mathrm{TC}=$ Total cost from transportation of fish from all landing sites to all markets.

$\mathrm{C}_{\mathrm{ij}}=$ Cost per ton (OR/ Ton) of fish transported form $\mathrm{i}^{\text {th }}$ landing site to $\mathrm{j}^{\text {th }}$ market.

$\mathrm{X}_{\mathrm{ij}}=$ Tons of fish transported from $\mathrm{i}^{\text {th }}$ landing site to $\mathrm{j}^{\text {th }}$ market.

$\mathrm{S}_{\mathrm{i}}=$ Quantity (Tons) of fish supplied from $\mathrm{i}^{\text {th }}$ landing site.

$\mathrm{D}_{\mathrm{j}}=$ Quantity (Tons) of fish demanded at $\mathrm{j}^{\text {th }}$ market.

The dual of above primal transport cost minimization model is as follows:

$$
\begin{array}{ll}
\text { Maximize: } & \mathrm{S}=\mathrm{D}_{\mathrm{j}} * \mathrm{~V}_{\mathrm{j}}-\mathrm{S}_{\mathrm{i}} * \mathrm{U}_{\mathrm{i}} \\
\text { Constrained to: } & \mathrm{V}_{\mathrm{j}}-\mathrm{U}_{\mathrm{i}} \leq \mathrm{C}_{\mathrm{ij}} \\
& \mathrm{V}_{\mathrm{j}}, \mathrm{U}_{\mathrm{i}} \geq 0
\end{array}
$$

where:

$\mathrm{U}_{\mathrm{i}}=$ Comparative locational value of the fish at landing site.

$\mathrm{V}_{\mathrm{j}}=$ Price of fish at market site in competitive market equilibrium.

The dual model estimates the optimal price at each output market, which equates supply and demand over the whole market. The outcome of this calculation represents shadow prices because they are the opportunity cost of an optimal allocation of fish between the various markets. The parameters $\mathrm{C}_{\mathrm{ij}}, \mathrm{S}_{\mathrm{i}}$, were estimated based on the field survey and $\mathrm{D}_{\mathrm{j}}$ were estimated using secondary data from 
the household income and expenditure survey conducted by the Ministry of National Economy, Oman (2003). Demand for fish consumption at Dubai was estimated based on data of fish imports to Dubai Central Market (DCM). The linear programming model was solved using Microsoft Excel Solver.

\section{Analysis and Results}

To illustrate the model the paper reproduces only the kingfish data and LP model. Similar data is available (Al-Abri, 2008) for the other species considered in the analysis (sardine and composite). Using fish prices at landing sites reported by truckers and the operating cost of transport estimated on survey data the variable cost (sum of operating cost of transport and purchase price of fish at landing site) of transporting a ton of kingfish from landing sites to markets were estimated and is given in Table 1.

Supply of kingfish from landing sites: As illustrated in Table 2, the sample of truckers transported 2,034 tons of kingfish per year. It was observed that nearly $72 \%$ of kingfish fish was transported to DCM and thus only $28 \%$ of the fish was delivered to domestic markets.

Consumer demand for kingfish at market sites: Table 3 shows the estimated annual demand for kingfish at market sites. The transportation model assumes that the fish market is equilibrated in terms of demand and supply from all landing sites and market sites. The sample estimate of supply of kingfish was 2034 tons per year. This quantity

Table 1. Variable cost ( $\mathrm{RO}^{1 /}$ ton) of transport: kingfish.

\begin{tabular}{lccc}
\hline \multirow{3}{*}{ Markets } & \multicolumn{3}{c}{ Landing Sites } \\
\cline { 2 - 4 } & Masirah & JBBA & Mahoot \\
\hline Ibri & 874 & 1250 & 1370 \\
Nizwa & 771 & 1233 & 1312 \\
Seeb & 799 & 1252 & 1370 \\
Dubai & 874 & 1304 & 1387 \\
\hline
\end{tabular}

${ }^{1}$ Rial Omani (RO) $=\$$ US 2.60 (May 2008).

Note: Sohar landing site did not have kingfish, hence was not considered in the analysis.

Table 2. Observed quantity (tons/year) of kingfish transported.

\begin{tabular}{|c|c|c|c|c|c|}
\hline \multirow{2}{*}{ Landing sites } & \multicolumn{4}{|c|}{ Markets } & \multirow{2}{*}{ Total } \\
\hline & Ibri & Nizwa & Seeb & Dubai & \\
\hline Masirah & 62 & 0 & 0 & 183 & 245 \\
\hline Jalan & 0 & 0 & 219 & 548 & 767 \\
\hline Mahoot & 73 & 219 & 0 & 730 & 1,022 \\
\hline Total & 135 & 219 & 219 & 1461 & 2,034 \\
\hline
\end{tabular}

of supply apportioned to the market sites based on the proportional demand of each site and the estimates are given in Table 3.

Optimized solution of the dual of transport cost minimizing model: The matrix of the cost minimizing dual linear transportation model with the optimized solution is given in Table 4. The $\mathrm{V}_{\mathrm{j}}$ 's are the optimal prices of fish at market site in competitive market equilibrium. (Recall that the observed unit variable cost includes the price paid for fish at landing sites, so the $\mathrm{U}_{\mathrm{i}}$ 's work in the model as an increment to the landed price to ensure that the variable costs are not exceeded in the optimization calculation).

The estimated optimal prices are compared with the observed prices of kingfish, in Figure 3. It is observed that except in Nizwa, where the observed price is higher than the optimal price, in all other markets the optimal and observed prices of kingfish are almost the same. This implies that, the transport function of the fish marketing system in Oman is efficient, contrary to the hypothesis of the study.

The optimal prices of sardine and composite fish were estimated using the same methodology adopted in estimating the optimal prices for kingfish. The optimal and observed prices of kingfish, sardines and composite fish are given in Table 5. A paired t-test indicated that a statistically significant difference between the optimal and observed prices did not exist $(\mathrm{t}=1.8989 ; \mathrm{n}=12)$. Acknowledging the implication of inadequacies of the small number of observations on robustness of statistical testing, it could be concluded that, since the observed and optimal prices of different fish prices at different markets are not significantly different, the transport function of fish market in Oman is efficient.

\section{Conclusion}

The analysis indicates that the transport function of fish markets in Oman is broadly efficient, and favors the supply of relatively more fish to export markets than domestic markets. Truckers also confirmed that the reasons for transporting fish to export markets instead of the domestic markets was because of profitability, and

Table 3. Estimated demand for kingfish at markets (tons/ year).

\begin{tabular}{lccccc}
\hline \multirow{2}{*}{ Item } & \multicolumn{5}{c}{ Markets } \\
\cline { 2 - 4 } & Ibri & Nizwa & Seeb & Dubai & Total \\
\hline $\begin{array}{l}\text { Estimated } \\
\text { demand }\end{array}$ & 1368 & 590 & 768 & 2196 & 4,922 \\
$\begin{array}{l}\text { Proportioned } \\
\text { demand }\end{array}$ & 0.28 & 0.11 & 0.16 & 0.45 & 1.00 \\
$\begin{array}{l}\text { Supply } \\
\text { apportioned to } \\
\text { demand }\end{array}$ & 565 & 244 & 317 & 907 & 2034 \\
\hline
\end{tabular}


Table 4. Dual transport cost minimizing model: kingfish.

\begin{tabular}{|c|c|c|c|c|c|c|c|c|c|c|}
\hline \multirow{4}{*}{$\begin{array}{l}\text { Maximize } D_{j} * V_{j}-S_{i} * U_{i} \\
\text { Solution } V_{j} \text { and } U_{j} \\
\text { Objective Function Coefficients }\end{array}$} & \multicolumn{10}{|c|}{$2,559,928$} \\
\hline & \multirow{3}{*}{$\begin{array}{c}1338 \\
V_{j}=1 \\
565\end{array}$} & \multirow{3}{*}{$\begin{array}{l}1312 \\
V_{j}=2 \\
244\end{array}$} & \multirow{3}{*}{$\begin{array}{l}1340 \\
V_{j}=3 \\
317\end{array}$} & \multirow{3}{*}{$\begin{array}{c}1387 \\
V_{j}=4 \\
907\end{array}$} & \multirow{3}{*}{$\begin{array}{c}541 \\
U_{i}=1 \\
-245\end{array}$} & \multirow{3}{*}{$\begin{array}{c}88 \\
U_{\mathrm{i}}=2 \\
-767\end{array}$} & \multirow{3}{*}{$\begin{array}{c}0 \\
U_{i}=3 \\
-1022\end{array}$} & & & \multirow{3}{*}{$\begin{array}{l}\text { Observed Unit } \\
\text { Variable } \\
\text { Cost (OR/ton) }\end{array}$} \\
\hline & & & & & & & & & & \\
\hline & & & & & & & & & & \\
\hline \multicolumn{11}{|l|}{ Constraints } \\
\hline $\mathrm{X}_{11}$ & 1 & & & & -1 & & & 796 & $<=$ & 874 \\
\hline$X_{12}$ & & 1 & & & -1 & & & 771 & $<=$ & 771 \\
\hline $\mathrm{X}_{13}$ & & & 1 & & -1 & & & 799 & $<=$ & 799 \\
\hline$X_{14}$ & & & & 1 & -1 & & & 845 & $<=$ & 874 \\
\hline$X_{21}$ & 1 & & & & & -1 & & 1250 & $<=$ & 1250 \\
\hline$X_{22}$ & & 1 & & & & -1 & & 1225 & $<=$ & 1233 \\
\hline$X_{23}$ & & & 1 & & & -1 & & 1252 & $<=$ & 1252 \\
\hline$X_{24}$ & & & & 1 & & -1 & & 1299 & $<=$ & 1304 \\
\hline$X_{31}$ & 1 & & & & & & -1 & 1338 & $<=$ & 1370 \\
\hline$X_{32}$ & & 1 & & & & & -1 & 1312 & $<=$ & 1312 \\
\hline$X_{33}$ & & & 1 & & & & -1 & 1340 & $<=$ & 1370 \\
\hline $\mathrm{X}_{34}$ & & & & 1 & & & -1 & 1387 & $<=$ & 1387 \\
\hline
\end{tabular}

Notes:

$\mathrm{V}_{\mathrm{j}}=$ Price of fish at market site $\mathrm{j}$ on competitive market equilibrium.

$\mathrm{U}_{\mathrm{i}}=$ Comparative locational value of the fish at landing site.

i landing sites $1=$ Masirah, $2=$ Jalan, $3=$ Mahoot

j markets; 1 =Ibri, 2 = Nizwa, 3 = Seeb, 4 = Dubai

$\mathrm{X}_{11}=$ Masirah-Ibri

$\mathrm{X}_{21}=$ Jalan-Ibri

$\mathrm{X}_{31}=$ Mahoot-Ibri

$\mathrm{X}_{12}=$ Masirah-Nizwaa

$\mathrm{X}_{22}=$ Jalan-Nizwaa

$\mathrm{X}_{32}=$ Mahoot-Nizwaa

$\mathrm{X}_{13}=$ Masirah-Seeb

$\mathrm{X}_{23}=$ Jalan-Seeb

$\mathrm{X}_{33}=$ Mahoot-Seeb

$\mathrm{X}_{14}=$ Masirah- Dubai

$\mathrm{X}_{24}=$ Jalan- Dubai

$\mathrm{X}_{34}=$ Mahoot- Dubai

Table 5. Observed and optimal fish prices (OR/ton).

\begin{tabular}{lccc}
\hline Fish Species & Market & Observed & Optimal \\
\hline Kingfish & Ibri & 1475 & 1338 \\
& Nizwa & 1800 & 1312 \\
& Seeb & 1375 & 1340 \\
& Dubai & 1533 & 1387 \\
Sardine & Ibri & 190 & 189 \\
& Nizwa & 200 & 169 \\
& Seeb & 220 & 191 \\
& Dubai & 251 & 243 \\
Composite & Ibri & 572 & 531 \\
& Nizwa & 485 & 383 \\
& Seeb & 595 & 669 \\
& Dubai & 650 & 653 \\
\hline
\end{tabular}

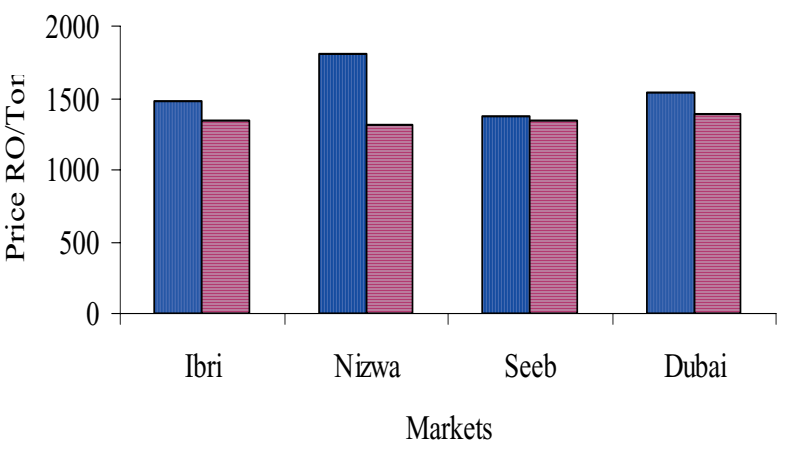

GObserved $\square$ Optimal

Figure 3. Observed and optimal sale prices of kingfish by market sites (OR/Ton). 
the ability to sell large quantities in export markets. Given that the transport function of the fish market in Oman is efficient, this trend of transporting to export markets is rational and will continue. The implication is that in the long-run domestic markets may have lesser availability of fish from its own fisheries. This may not be considered to be equitable although it is efficient. Policy makers may have to recognize the trade off between efficiency and equity implications of the fisheries markets in Oman and make policy decisions accordingly.

\section{References}

Al-Abri, Khamis. S. 2008. Efficiency of Fish Markets in Oman: Transport Modeling Analysis. Unpublished MSc thesis, Sultan Qaboos University (SQU), Sultanate of Oman.

Al-Jabri, O. 1999. Fresh Fish Markets in Oman: A Market Integration Analysis. Unpublished MSc thesis, SQU, Sultanate of Oman.

Al-Jabri, O., A. Omezzine and H. Boughanmi. 2003. Fresh fish markets in Oman: a price integration analysis. Journal of International Food and Agribusiness Marketing 14:77-93.

Bush, S.R. 2004. Scales and sales: changing social and spatial fish trading networks in the Siiphandone Fishery, Lao PDR. Singapore Journal of Tropical Geography 25:32-50.

Borisova, T., G. D'Souza, D. Miller and C. Zabriskie. 2004. Optimum Shipment Patterns for West Virginia Aquaculture Products - PART I: Growers, WVU Division of Resource Management Paper RESMWP04-01. June 2004. 31 pp.

Dorfman, R., P.A. Samuelson and R.M. Solow. 1958. Linear Programming and Economic Analysis, Rand Cooperation.

Dubai Municipality. 2004. Statistical Year Book. Dubai Municipality, UAE.
Eddie, G.C. 1983. Road Transport of Fish and Fishery Products. FAO, Fisheries Technical Paper, 232, FIPP/ T232, Rome.

International Centre for Living Aquatic Resource Management (ICLARM) 1999. ICLARM Strategic Plan 2000-2020, Makati City: ICLARM.

Ministry of Agriculture and Fisheries (MAF) 2003. Fisheries Statistical Books. Ministry of Agriculture and Fisheries, Sultanate of Oman.

Ministry of Agriculture and Fisheries (MAF) 2004. Fisheries Statistical Books. Ministry of Agriculture and Fisheries, Sultanate of Oman.

Ministry of National Economy (MNE). 2006. Statistical Year Book, 2005. Ministry of National Economy, Sultanate of Oman.

Ministry of National Economy (MNE). 2003. Household Survey Data, Ministry of National Economy, Sultanate of Oman.

Omezzine, A., H. Boughanmi and H. Al Oufi. 2003. Demand elasticities of fresh fish commodities in Oman. Journal for Scientific Research-Agricultural Sciences 8:55-61.

Omezzine, A., L. Zaibet and H. Al-Oufi, 1996. The marketing system of fresh fish products on the Masirah Island in the Sultanate of Oman. Marine Resources Economics 11:203-210.

Smith, Janna D., C.R. Cassady, R.O. Bowden and L.M. Ainsworth. 2007. Optimizing Delta and Pine Land Company's Bag Seed Distribution, http: //www.ise.mastate.edu/ncit/

Thie, P. 1998. An Introduction to Linear Programming and Game Theory. Department of Mathematics, Boston College, USA.

Zaibet, L., H. Boughanmi, T. Al Hinai and A. Al Marshudi. 2004. Internationalization of Oman fisheries firms after the European Union ban. Journal of Agricultural and Marine Sciences-Agricultural Sciences 9:1-6.

Received: May 2008

Accepted: March 2009 